\title{
ФИЛОЛОГИЯ
}

(специильность: 10.02.19)

\section{УДК 81}

\section{О.А. Полякова}

Ростовский государственный

экономический университет (РИНХ)

2. Ростов-на-Дону, Россия

\section{Е.В. Федорович}

Ростовский юридический институт

министерства внутренних дел Российской Федерации

2. Ростов-на-Дону, Россия

redaction-el@mail.ru

\section{Л.М. Жолос}

Южный федеральный университет

2. Ростов-на-Дону, Россия.

redaction-el@mail.ru

\section{ЛИНГВОСТИЛИСТИЧЕСКИЕ ОСОБЕННОСТИ ТЕКСТА КОНСТИТУЦИИ США}

\section{[Olga A. Polyakova, Ekaterina V. Fedorovich, Lyudmila M. Zholos Linguastylistic features of the US Constitution text]}

The linguistic and stylistic features inherent in the text of the Constitution are examined, namely its structural, lexical, grammatical and stylistic characteristics. Analyzing the structural features, it should be noted that the structure and location of the text is of great importance. In its form, the US Constitution is codified. The text of the US Constitution is characterized by a high degree of struc ture, while the text of the Constitution should be clear to any reader - a citizen of the state or a per son who is interested in reading this document.

Key words: text, US constitution, linguistic-stylistic features, code.

Конституция относится к ориентационным жанрам политического дискурса, характер текста носит информационно-прескриптивный характер. Рассмотрев природу языка Конституции США, можно сделать вывод, что текст отно- 
сится к языку права. В данном исследовании рассматриваются лингвостилистические особенности, присущие тексту Конституции, а именно его структурные, лексические, грамматические и стилистические характеристики.

Анализируя структурные особенности, следует отметить, что структура и расположение текста имеет огромное значение. Конституция США считается первой в мире конституцией в современном понимании. Она состоит из преамбулы и семи статей, за время действия Конституции были приняты двадцать семь поправок, которые являются ее неотъемлемой частью. Преамбула к конституции США содержит единственное предложение. Сама по себе преамбула не является источником прямого действия, а только разъясняет основное назначение Конституции. По своей форме Конституция США является кодифицированной. Тексту Конституции США свойственна высокая степень структурированности. Он разделен на главы (Articles), а они в свою очередь на разделы (Sections), каждый из которых выделяется в отдельный абзац. По своим размерам разделы сильно отличаются друг от друга. Например, в первой главе первый раздел состоит всего лишь из одного предложения, в то время как второй раздел этой же главы растянулся на несколько абзацев. Такая строгая организация текста связано с его целью: четко и точно сформулировать условия общественного договора, от которых будет зависеть дальнейшее управление государством. Конституции свойственна высокая степень сегментации также для большего удобства просмотра или поиска нужной статьи. Отметим, что ни главы, ни разделы не имеют названий. Можно предположить, что это связано с тем, что содержание самих разделов является лаконичным, информативным и не нуждается в заголовке в качестве функции выделения основной мысли абзаца. Рассмотрим пример:

Article 1. Section. 1. All legislative Powers herein granted shall be vested in a Congress of the United States, which shall consist of a Senate and House of Representatives.

Section. 2. The House of Representatives shall be composed of Members chosen every second Year by the People of the several States, and the Electors in each State shall have the Qualifications requisite for Electors of the most numerous Branch of the State Legislature.

В некоторых разделах имеются перечисления, особенность которых заключается в том, что каждый пункт начинается с новой строки, избегая 
нагромождения в одном предложении. Особое внимание следует уделить преамбуле, так как она значительно отличается от основного текста. Итак, текст Конституции США имеет строгую архитектонику, что придает ему точность, четкость, ясность.

Рассмотрев структурные особенности текста Конституции США, перейдем к его лексическим характеристикам. Совокупность таких факторов как цель высказывания, функции текста, реципиент и адресат обусловливают следующие черты данного жанра с точки зрения лексики: точность изложения, объективность, конкретность.

Например: We the People of the United States, in Order to form a more perfect Union, establish Justice, insure domestic Tranquility, provide for the common defence, promote the general Welfare, and secure the Blessings of Liberty to ourselves and our Posterity, do ordain and establish this Constitution for the United States of America.

Местоимение we указывает на личную семантику субъекта, что является чертой эмоциональной информации. В тексте Конституции США отсутствует эмоционально-оценочная или эмоционально-окрашенная лексика, а в случае ее присутствия она потеряла бы свою оценочную функцию.

В тексте отсутствуют какие-либо образные средства, т. е. гиперболы, метонимии, метафоры, что также связано с функцией точности и избежанием нескольких толкований слова или фразы. В тексте Конституции США встречаются латинские выражения, например: The Senate shall chuse their other Officers, and also a President pro tempore, in the Absence of the Vice President, or when he shall exercise the Office of President of the United States. No Bill of Attainder or ex post facto Law shall be passed. Они получили терминологический характер, а также служат для большей торжественности и как дань традиции, поскольку в других сферах речи подобные выражения не встречаются (редко в целях придания определенной образности). Торжественность придает тексту некую эмоциональность, побуждая чувство почитания закона. Основу данного текста составляет терминологическая лексика. Так как текст принадлежит к законодательной сфере, термины также используются законодательные и политические: The House of Representatives shall be composed of Members chosen every second Year by the People of the several States, and the Electors in each State shall have the Qualifications requisite for Electors of the most 
numerous Branch of the State Legislature. The House of Representatives shall chuse their Speaker and other Officers; and shall have the sole Power of Impeachment. Every Order, Resolution, or Vote to which the Concurrence of the Senate and House of Representatives may be necessary (except on a question of Adjournment) shall be presented to the President of the United States; and before the Same shall take Effect, shall be approved by him, or being disapproved by him, shall be repassed by two thirds of the Senate and House of Representatives, according to the Rules and Limitations prescribed in the Case of a Bill. Термины служат для передачи объективности когнитивной информации.

В тексте преобладают слова французского происхождения с суффиксами -tion, -sion, - ment, -ture, -епсе, относящиеся к словообразовательным моделям с абстрактной семантикой: Qualification, enumeration, election, Expiration, Resignation, Indictment, Punishment, Regulation, Emolument, Reconsideration, Insurrection, Expenditure, Legislation. Вышеперечисленные слова передают абстрактность когнитивной информации в тексте. Далее, можно увидеть широкий пласт обще-книжной лексики, который также показывает объективность и абстрактность когнитивной информации: Appointment, Inhabitant, Affirmation, Judgment, disqualification, Majority, Attendance, Penalty, Secrecy, Compensation, Authority, amendment, Objection, Limitation, Bankruptcy, Capture, Appropriation, Government, Invasion, Migration, Importation, Preference. Также общекнижные слова показывают направленность текста не только на узкий круг специалистов (политиков и т.д.), но и на массового реципиента.

Текст Конституции должен быть понятен любому читателю - гражданину государства или человеку, который заинтересован в прочтении этого документа. В процессе исследования также было выявлено некоторое количество устаревших слов. В большинстве случаев, это связано с орфографией, то есть используемое слово изменило свое написание: But if there should remain two or more who have equal Votes, the Senate shall chuse from them by Ballot the Vice President. Указанное написание слова chuse (ныне choose) связано с датой создания Конституции США (1787 год), когда правила грамматики и лексический пласт отличались от ныне существующих. Также были обнаружены встречающие только в официально-деловом стиле речи местоименные наречия: Herein, thereof, otherwise, nevertheless, whereof, likewise, throughout, whatsoever. Языковой фон в материале исследования также образует нейтральный 
слой лексики, то есть слова, лишенные какой-либо стилистической окраски, упрощающие восприятие когнитивной информации: Consequence, Monday in December, Desire, Present, Member, to compel, Case, Person, Place, law, Power, subject, Money, State, pay, actually.

Следующей отличительной чертой текста Конституции США можно назвать отсутствие компрессивности информации. Не используются другие знаковые системы, например, для записи чисел: Two thirds of the Senate, two thirds of that House, two Years, to the Year one thousand eight hundred and eight. Отсутствуют лексические сокращения, показывающие плотность когнитивной информации. Итак, все вышеупомянутые лексические особенности соответствуют функции Конституции, а именно - точно и недвусмысленно определить условия, связывающие участников документа (граждан и государство).

Грамматические особенности текста Конституции США, а именно морфологические и синтаксические также были проанализированы. Преамбула состоит из одного простого предложения, осложненного однородными сказуемыми, чтобы перечислить поставленные задачи. Подлежащее, выраженное местоимением и существительным we the People, служит для усиления речи. Также, мы встречаем конструкцию do ordain and establish, которая служит для эмфазы текста преамбулы. Тексту Конституции свойственен безличный характер речи. Лицо оговаривается только в преамбуле Конституции для установления ясности, то есть становится понятно, кто принимает нижеописанные условия. Далее можно увидеть исключительно пассивные конструкции, показывающие, на кого направлено действие, а именно кому предписано выполнять данные правила, но не от кого исходит само действие.

Например: We the People of the United States ... do ordain and establish this Constitution for the United States of America. В преамбуле четко определено лицо, которое принимает условия данного соглашения. Далее (статья 1, раздел 2): No Person shall be a Representative who shall not have attained to the age of twenty five Years. Representatives and direct Taxes shall be apportioned among the several States. The Number of Representatives shall not exceed one for every thirty Thousand, but each State shall have at Least one Representative.

Подлежащее в вышеуказанных предложениях также присутствует, однако речь идет о долженствовании, что придает тексту торжественность, которая побуждает читателя чтить данный закон. Текст Конституции написан с помо- 
щью времен группы Indefinite: Present Indefinite модальных глаголов: Each House may determine the Rules of its Proceedings, punish its Members for disorderly Behaviour, and, with the Concurrence of two thirds, expel a Member. Редкое использование времен группы Past и Perfect говорит нам об объективности когнитивной информации. Рассматривая разные контексты, можно увидеть, что почти 90\% предложений содержат пассивный залог с модальным словом shall. The Privilege of the Writ of Habeas Corpus shall not be suspended, unless when in Cases of Rebellion or Invasion the public Safety may require it. Также можем наблюдать использование модального глагола may. ...he may require the Opinion, in writing, of the principal Officer in each of the executive Departments.

Указанные модальные глаголы со значением возможности и необходимости говорят нам о таком свойстве информации, как оперативность. Это указывает на строгое выполнение данных правил. В тексте мы встречаем исключительно прямой порядок слов. Инвертированный порядок слов отсутствует, так как эта черта относится к средствам выразительности, которые также отсутствуют (как было указано выше). Что касается средств языка, используемых на уровне синтаксиса, основной прием в данном тексте - повтор. Одно и то же имя существительное может употребляться в соседних предложениях, или несколько раз в рамках одного предложения, при этом его не заменяют местоимением. В других стилях речи эта тавтология считалась бы серьезным изъяном. Например: All Bills for raising Revenue shall originate in the House of Representatives; but the Senate may propose or concur with amendments as on other Bills. Every Bill which shall have passed the House of Representatives and the Senate, shall, before it become a law, be presented to the President of the United States. В тексте Конституции такое употребление слов обусловлено его функцией: таким образом, избегают двоякого толкования текстов документов. Это же правило справедливо для всех остальных жанров официально-делового стиля. Около 50 \% данного текста составляют простые двусоставные предложения, осложненные:

1) инфинитивными конструкциями: The Senators and Representatives shall receive a Compensation for their Services, to be ascertained by Law, and paid out of the Treasury of the United States.

2) однородными членами: The President, Vice President and all Civil Officers of the United States, shall be removed from Office on Impeachment for and Conviction of, Treason, Bribery, or other high Crimes and Misdemeanors. 
3) распространенными обстоятельствами: Neither House, during the Session of Congress, shall, without the Consent of the other, adjourn for more than three days, nor to any other Place than that in which the two Houses shall be sitting.

Таким образом, проанализировав сущность языка Конституции США, а также выявив лингвостилистические особенности текста, мы пришли к выводу, что текст Конституции относится к языку права. Конституция сама себя называет законом, что предполагает ее связь с языком, на котором обычно пишутся законы. Текст Конституции полон многочисленными юридическими терминами. Некоторые из этих терминов однозначно относятся к языку права. Другие носят двусмысленный характер, имея как ней тральное, так и юридическое значение. А третьи имеют нейтральное значение, но могут также, в зависимости от результатов дальнейших исследований, иметь юридическое значение.

$$
\text { Л И }
$$

1. The Constitution of the United States. The Bill of Rights\&All Amendments. https://constitutionus.com/ (reference date: 10.12.2020)

$$
\begin{array}{lllllllllll}
\mathrm{R} & \mathrm{E} & \mathrm{F} & \mathrm{E} & \mathrm{R} & \mathrm{E} & \mathrm{N} & \mathrm{C} & \mathrm{E} & \mathrm{S}
\end{array}
$$

1. The Constitution of the United States. The Bill of Rights\&All Amendments. https://constitutionus.com/ (reference date: 10.12.2020) 